organization. Those in authority regard its maintenance as necessary not only because of the respect which it enjoys abroad but also for the purpose of linking research with industry. The necessary cooperation between the State Council for Research and the Kaiser Wilhelm Gesellschaft is for the present guaranteed; first, by the common supervision of both bodies by the Reichsminster (Herr Rust), secondly, by the appointment of the directors of two of the Kaiser Wilhelm Institutes as heads of Departments of the State Council for Research, and finally by my own membership of the Senate of the Kaiser Wilhelm Gesellschaft. Later it will be essential, by suitable measures, to bring the directors of all the Kaiser Wilhelm Institutes into closer relations with the State Council for Research. The Ministerial decree founding the Council," he added, "designates the furtherance of the Four Year Plan as one of the Council's most important tasks."

The careers of the heads of all departments of the new Council are set forth in the publication, those of the president and vice-president being stated as follows :

"Artillery-General Professor Karl Becker. Born 1879. From 1900 Artillery Officer. 1906-14 in the Military Technical Academy and active as referee in ballistics. $1914-16$ on active service in charge of a $42 \mathrm{~cm}$. battery and then until the end of the War ballistic expert of the Artillery Investigation Commission. From 1919, ballistic expert in the Armaments Office and from 1926 director of its Projectiles and Munitions Department. Since 1932, as director of the Munitions Office Investigation Committee, he has been responsible for the entire technical develop. ments of the Army. In 1933 he became professor ordinarius of military technics, physics and ballistics at the Technische Hochschule in Berlin."

"Staatsminister Dr. Otto Wacker. Vice-president of the State Council of Research. Head of the office for Learning (Wissenschaft) in the Ministry of Learn. ing, Training and National Education. Born 1899. During the War he was a 'front fighter' on the western front. After the War he studied architecture at the Technische Hochschule at Karlsruhe. Since 1925 he has studied German literature and history at Freiburg, where he took his doctorate. During the revolutionary period he became a district leader (Kreisleiter). He also wrote for the Baden journal Der Führer. In 1933 he became Kultus and Education Minister of Baden. With the nationalization of justice in 1934, he became Minister of Justice for Baden. $\mathrm{He}$ is also an SS Commander (Oberführer)."

The fourteen departments already organized by the Council are as follows : (1) Physics, including mathematics, astronomy and meteorology ; (2) Chemistry and physical chemistry, under the direction of General Becker himself; (3) Power materials ; (4) Organic industrial materials, artificial products, rubber, textiles, fats, cellulose; (5) Non-ferrous metals; (6) Geology, including mineralogy and geophysics; (7) Agriculture and general biology, ineluding zoology and botany ; (8) Forestry and timber research ; (9) Military science and technics, under General Becker himself; (10) Electro-technics; (11) Mining and smelting ; (12) Iron and steel ; (13) Medicine, including race research and race biology; (14) Military medicine.

\title{
Medical Research in Canada
}

\section{Medical Research Committee}

\begin{abstract}
A COMMITTEE to study the organization of medical research in Canada has been appointed by the National Research Council. This action was taken on the recommendation of a nationwide conference on medical research held in Ottawa recently, which was attended by representatives of all the medical schools, organizations and institutions concerned in medical research, including the provincial departments of health, the Department of Pensions and National Health, and the National Research Council. Sir Frederick Banting has been appointed chairman of the new committee. The president of the National Research Council, the deputy minister of the Department of Pensions and National Health, the president of the Canadian Medical Association, and the president of the Royal College of Physicians and Surgeons of Canada are to be ex-officio members of the committee. To complete the personnel of the committee invitations have been extended to twelve distinguished members of the medical profession who have a comprehensive knowledge of Canada's requirements in medical research.
\end{abstract}

It has been suggested by many members of the medical profession that the formation of this committee on medical research under the National Research Council might well be a first step towards the formation of a medical research council for Canada similar to that which exists in Great Britain. Commenting on this suggestion, Major-General McNaughton, president of the National Research Council, speaking at the conference, said that "the National Research Council is approaching the problem of organization of medical research at present as a preliminary measure only. When a purely medical research council becomes necessary, there will be no opposition whatever from the National Research Council. In fact, the National Research Council will give every assistance possible in order to help a movement that in the opinion of the Council is very important for the welfare of the people of Canada."

The immediate purpose of the committee is defined in the terms of reference, which are: $(a)$ to receive suggestions for requirements in respect of medical research and in matters related thereto; $(b)$ to consider by whom the investigations required can best be carried out and to make proposals accordingly ; (c) to correlate the information when secured and to make it available to those concerned; $(d)$ to do such other things as the committee may deem advisable to promote medical research in Canada.

The conference agreed that the scope of the new committee's activities should not be limited to particular subjects, but that it should be empowered 
to investigate the whole field of medical research in Canada. One of the first steps to be taken by the committee will be to make a survey of the work in progress at various centres to determine how the activities of the various institutions concerned may be developed to the best possible advantage.

A remarkable record of individual research achievements was revealed in the prepared statements presented at the conference, but the need of bringing the available information together through a central body which could then make it more readily accessible to all concerned was stressed by nearly every speaker. The new committee undertakes its task with the full support and under the direct leadership of the medical profession as a whole in Canada. Results of far-reaching importance are expected in the planning and co-ordination of medical research that will be possible through this new committee. Better dissemination of information regarding the multitude of projects that are being carried on by skilled workers in the hospitals and laboratories of the Dominion will greatly enhance the opportunities of the research workers to make their efforts count.

\section{Progress in Road Research*}

$\mathrm{O}^{\mathrm{N}}$ E of the interesting features of the report of the Road Research Board (director of research, Dr. R. E. Stradling) recently issued by the Department of Scientific and Industrial Research is that which concerns the method of studying the problem of skidding by means of texture prints. These are obtained by inking a portion of the actual road surface and rolling over it a perfectly smooth tyre which then impresses on a sheet of paper an exact record of this portion of the road surface. The object is to study the texture of the surface of a road in order to ascertain its relation to the skidding resistance of the road and to its wearing properties.

The importance of the method can be understood from the statement made in the report that the skidding characteristics of road surfaces are largely determined by the total area of contact between tyre and road and by the number of individual isolated areas of contact into which the total area is divided. In order that, when the road is wet, the liquid on it can escape as the tyre rolls over the road, these small areas of actual contact must be surrounded by channels of adequate size. If the channels are too small, these small areas of contact will, in effect, be merged into one another and the surface will behave as if quite smooth. "An examination of texture prints taken from roads known to be slippery has shown", says the report, "that on these the tyre makes contact with the road over almost the entire area of the ellipse of contact while the number of individual contacts in this area is small". On the other hand, where the sideway force coefficient is high, the proportionate area of actual contact is found to be less while the number of individual areas of contact is much higher. The same is regarded as true of tyre-tread patterns.

In two other directions, the road texture print is an aid to the study of surface problems. By their means the seasonal changes in the slipperiness of roads are being more closely investigated. These, it is believed, depend largely on changes of the surface texture. Then, again, apart from the question of slipperiness, a series of prints is of value in exhibiting the progressive wear of a road surface and of enabling this and other surface changes to be recorded and followed.

The motor-cycle and side-car equipment described.

* Department of Scientific and Industrial Research. Report of the Road Research Board, with the Report of the Director of Road Research, for the Year ended 31st March, 1937. Pp. viii +120 . (London: H.M. Stationery Office, 1937.) 38. net. in previous reports continues to be employed on skidding tests and is noted as having been employed on surfaces prepared of cast-iron blocks, ordinary wood blocks and special blocks. A sharp fall in the value of the sideway force coefficient as from dry to wet conditions is very noticeable in the results. The higher powered machine now available permits of tests at speeds from 30 to 50 miles an hour, and it would appear that while, on most surfaces, the coefficient tends to reach a steady value in this range, on some there are indications of a continued fall and therefore of increased risk of skidding.

Specimens of mud from surfaces giving low skid coefficients are being studied and their lubricating properties compared with those of water in order to determine to what extent this agency affects slipperiness. The report briefly discusses the question whether mud films on a road during a fog produce a specially slippery surface, and the conclusion tentatively reached is that, from the several points of view quoted, the tendency is towards increased slipperiness.

Tests of road roughness by the special vehicle designed for the purpose and capable of detecting and recording irregularities of more than one fifth of an inch and of integrating them, show a total irregularity, on the best roads, of 75-85 inches a mile. Main roads commonly give $100-250$ inches, and very rough roads $500-800$ inches a mile.

In investigations on the durability of road construction by means of the full-size lorry driven round a track of $55 \mathrm{ft}$. radius, experience indicates the desirability of correlating these trials more closely to actual road conditions. In conjunction with a traffic census, records of the periods of wetness and of dryness will afford valuable information. Instruments have been devised for this purpose, the method employed to detect whether the road is wet or dry depending on the fact that the electrical resistance of the film of moisture on the road, measured between two contact strips $3 \mathrm{ft}$. long and 18 inches apart, is of the order of one fifth megohm when the road is wet, and some 50 megohms when visibly dry.

Other lines of investigation include the impact forces to which traffic subjects a road, the causes of failure of embankments and cuttings in wet seasons, tests of road materials and experiments on the aggregate vibration method of concrete control. An extensive trial of this method is being made by the County Engineer of Surrey in the construction of the Mickleham By-Pass Road. 